\title{
The debatable identity in Isaiah 62:5
}

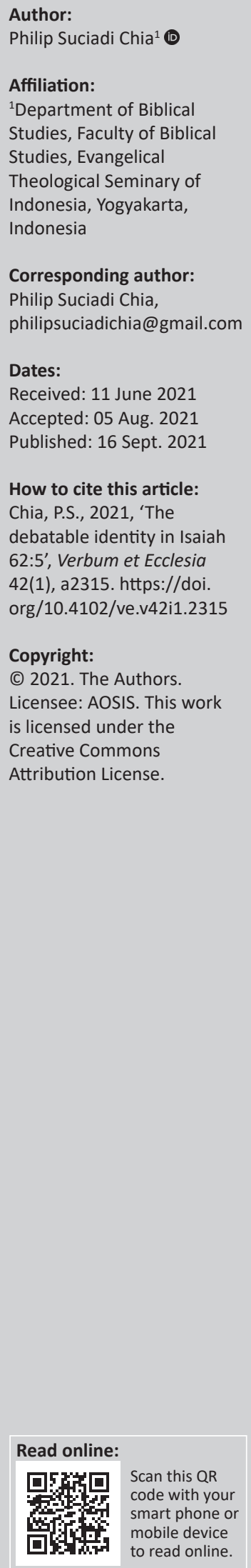

In Isaiah 62:5, there are three major translations of who will marry 'you' or 'Zion' based on the immediate context (Is 62:1). Firstly, the most common reading is 'your sons' (Amplified Bible [AB], American Standard Version [ASV], Berean Study Bible [BSB], Catholic Public Domain Version [CPDV], Douay-Rheims Bible [DRB], English Standard Version [ESV], King James Version [KJV], New International Version [NIV], New American Standard Bible [NASB], Smith's Literal Translation [SLT], World English Bible [WEB]). Secondly, the scholars reading preference is 'your builder', which refers to 'God' based on Psalms 147:2. This reading is adopted by Coverdale Bible of 1535, New Revised Standard Version (NRSV) and Good New Bible (GNT). Lastly, although the translation 'builders' is the least favourable reading, LSV and YLT use this reading. This research, therefore, attempts to argue for 'your sons' translation as the original reading through textual criticism as the methodology.

Intradisciplinary and/or interdisciplinary implications: This article is a combination of textual criticism studies with translations.

Keywords: ancient translations; modern translations; textual criticism; Isaiah 62:5.

\section{Introduction}

The identity of Zion's spouse is debatable in modern Bible translations. The most common reading is 'your sons' (Amplified Bible [AB], American Standard Version [ASV], Berean Study Bible [BSB], Catholic Public Domain Version [CPDV], Douay-Rheims Bible [DRB], English Standard Version [ESV], King James Version [KJV], New International Version [NIV], New American Standard Bible [NASB], Smith's Literal Translation [SLT], World English Bible [WEB]). This translation reads a pure consonantal text בניך from the noun בִּך

The scholars reading preference is 'your builder' (Biblia Hebraica Stuttgartensia apparatus, Coverdale Bible of 1535, NRSV and GNT). There are a few reasons behind this second translation: Firstly, Psalms 147:2 that sees God as the builder of Jerusalem and the gatherer the exiles of Israel (NIV) and secondly, Leviticus 18:7-8 that clearly states that an incestuous copulation is strongly prohibited in the God's law. Deuteronomy 27:23 also curses anyone who sleeps with his mother-in-law.

The least favourable reading is 'your builders' (Literal Standard Version [LSV] and Young's Literal Translation [YLT]). Based on Isaiah 60:10 and 61:4, these 'builders' refer to 'the foreigners'. This translation reads a pure consonantal text בניך from the verb בנה.

Consequently, these three possible readings reveal that this identity is highly disputable amongst the modern translation.

\section{Methods and its findings: Textual criticism External evidence}

In this methodology, this research will present the reading from ancient sources such as Aleppo codex (eds. Elliger \& Rudolph 1997), 1QIsa ${ }^{a}$ (Parry \& Qimron 1999), 1QIsa ${ }^{b}$ (Ulrich, Flint \& Abegg 1990), Peshitta (eds. Romeny \& Van Peursen 1993), Targum (Chilton 1987), Septuagint (Ziegler 1939) and Vulgate (Kennicott 1776-1780; eds. Weber et al. 1983). The presentation of ancient readings is summarised in Table 1.

In addition to the primary reading on the text, this research will also incorporate the apparatuses of those ancient texts. 
TABLE 1: Presentation of ancient readings.

\begin{tabular}{|c|c|c|c|}
\hline Source & Text & Translation & Vorlage \\
\hline Aleppo & 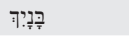 & Your sons & 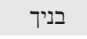 \\
\hline $1 Q$ lsa $^{a}$ & בניך & Your sons or Your builders & 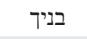 \\
\hline $1 Q I s a^{b}$ & בניך & Your sons or Your builders & בניך \\
\hline Peshitta & טنصر & Your sons & בניך \\
\hline Targum & 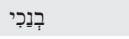 & Your sons & בניך - - - l \\
\hline Septuagint & oi vioí oou & Your sons & בניך \\
\hline Vulgate & te filii & Your sons & בניך \\
\hline
\end{tabular}

\section{Aleppo Codex}

Apparatus of Aleppo Codex does not list any witness that contains the reading of 'your builders' or 'your builder'. Nevertheless, the editors of BHS propose another reading of

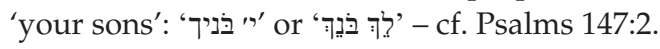

\section{QIsa $^{\mathrm{a}}$}

There is no apparatus or no variant regarding the reading of בניך.

1 QIsa ${ }^{b}$

There is no apparatus or no variant regarding the reading of בניך.

\section{Peshitta}

There is no apparatus or no variant regarding the reading of כسحص.

\section{Targum}

There is no apparatus or no variant regarding the reading of רִנְכִ

Septuagint

There is no apparatus or no variant regarding the reading of oi vioí $\sigma o v$.

Vulgate

Both Kennicott and Weber reveal no variant regarding the reading of te filii.

In conclusion, the externalevidence provides some information. Firstly, most of the ancient sources have 'your sons'. Secondly, the translation of 'your builders' occurs because of the other possibility of translation of a pure consonantal text of בניך' Thirdly, the translation of 'your builder' or 'בנך' is certainly not attested in ancient texts. As a result, the external evidence favours the reading of 'your sons'.

\section{Internal evidence}

\section{The evaluation of 'your builders'}

This translation comes from another possibility of a pure

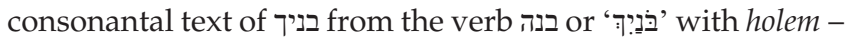

TABLE 2: Structure of Isaiah 62:5 from McKenzie and Whybray.

\begin{tabular}{|c|c|c|c|}
\hline Verse & Hebrew & Hebrew & Comparison \\
\hline $62: 5 a$ & 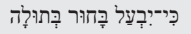 & 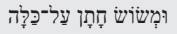 & 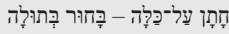 \\
\hline $62: 5 b$ & 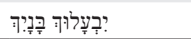 & 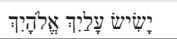 & 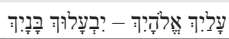 \\
\hline
\end{tabular}

Source: McKenzie, J.L., 1968, Second Isaiah, Doubleday, Garden City, NY; Whybray, R.N., 1990, Isaiah 40-66, Wm. B. Eerdmans, Grand Rapids, MI.

patah as its vowels. Although the incestuous sexual and בנך problem, this translation has a major problem. Isaiah 60:10 reveals the identity of this 'builders' as the servants of God's people, and not husband. Isaiah 61:4-5 continue that this 'builders' will be God's people vine dressers and farmers. Also, the lexical study בניך occurs as 'your sons' (Chia \& Juanda 2019:8-13).

\section{The evaluation of 'your builder'}

The major strength of this translation is solving the incestuous marriage in Isaiah 62:5 because Leviticus 18:7-8 prohibit this type of sexual relationship and Deuteronomy 27:23 curses the incestuous marriage. Also, Lowth (Lowth 1778:618-619), Duhm, Marti, Barthélemy (Barthélemy 1986:428-429; Duhm 1902:418; Marti 1900:389), McKenzie and Whybray (McKenzie 1968:185; Whybray 1990:389) endorse this translation through a parallelism argument. Table 2 is taken from McKenzie and Whybray.

This translation, nevertheless, has some challenges. Barthélemy argued that translators occasionally ignore a harder reading to advocate a reading obtained by a conjectural emendation (Barthélemy 2012:92). Thus, this reading might not be an original reading. Also, this research argues that Isaiah $62: 5$ should be read together with Isaiah $62: 4$ because these verses are presented in A-B-A-B structure. Isaiah 62:4a declares the result of Zion's restoration, whilst Isaiah 62:4b-5 provides two reasons - emotional and marriage relationship of Isaiah 62:4a.

Consequently, both McKenzie and Whybray mistakenly compare Isaiah 62:5a with 62:5b. In fact, Isaiah 62:4-5 symbolically picture the joyful and populous land of Zion through emotional and marriage relationship. Baker and Walton explain that this marriage pictures the protection and providence of the land of Zion (Baker \& Walton 2009:430).

\section{The evaluation of 'your sons'}

This translation reads a pure consonantal text בניך from the

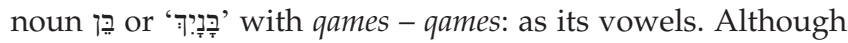
this translation has an incestuous problem, it is supported by three major arguments. Firstly, Barthélemy argues that ancient scribes and translators tend to simplify the difficult text through lexical, grammatical and stylistic forms, which is called as 'facilitating'. In other words, the harder text may be considered as the original (Barthélemy 2012:90). The reading of 'your sons' is definitely a more difficult reading because of the incestuous copulation. Secondly, God promises that his people will possess the land (Is 14:1; 49:20; 54:3; 60:4, 9, 21-22). Contextually, these people will benefit from their land as it is promised in Isaiah 62:9 (Chia \& Juanda 2019:8-13). 
Thirdly, the word בניך appears nine times in the book of Isaiah (49:17, 22, 25; 51:20; 54:13 [two times]; 60:4, 9; 62:5). These verses refer בניך as 'your sons'. Therefore, it is plausible to think that Isaiah 62:5 follows the rest of the verses.

The next question, then, how are we going to solve an incestuous problem? There are two primary interpretations. The first interpretation is derived from Ephrem the Syrian. He interprets Christ as the husband and church as Zion such as in Ephesians 5:23 (ed. Lamy 1882-1902:2, 185). Eusebius of Caesarea also reads Isaiah 62:5 Christologically: the marriage between Christ and the church. He sees this marriage eschatologically. Christ will receive his bride and establish the holy church from the mature members of the former people and from the new people of the gentiles in the new age of the kingdom of Christ (ed. Elowsky 2013:301). The major problem with this interpretation is Isaiah 62:5 does not point out to Christ or the church. This text does not allow us to interpret the restoration of Zion spiritually.

The second interpretation is derived from the verb יבעלוך. The common meaning of בעל is 'to possess'. It is also related to 'wife' in Hebrew (Brown et al. 1952:127). Oswalt, the proponent of this translation, uses Judges 9:2 as its reference. ${ }^{1}$ He defends the translation of a dweller or possessor of the land more than a status as a husband. He also interprets the name of the land 'בעולה' in Isaiah 65:4 as 'belongs to' or 'to dwell with' instead of 'married'. ${ }^{2}$ He argues that 'to dwell in' is more sensible in the context than 'married'. The reading of 'your sons will dwell in you' is more reasonable than 'your sons will marry you' because he believes that the relational aspect is important to Isaiah. It is not merely that the land will be re-inhabited, but that it will be in a relationship of belonging. This emphasis on relationship seems to be the reason of 'to possess' or 'to dwell in' reading (Oswalt 1998:579). Septuagint, Targum and Vulgate agree with Oswalt's proposal, although Peshitta translates as 'a sexual intercourse' or 'حصلمصر'. Aleppo codex, 1QIsa a and 1QIsa text could be translated either way: to dwell or to marry. Table 3 summarises ancient sources that concur Oswalt's proposal.

The first major problem of this translation is the language of Isaiah 62:5a. It says, 'for a young man "יבעלוך" a virgin'. If we translate 'יבעלוך' as 'to dwell in' or 'to possess', then the emotional and marriage relationship would be disappeared from the reading. Also, it would be an inappropriate relationship if a young man possesses a virgin. On the other hand, it would be an incomprehensive picture to imagine a young man dwells in a virgin. The second major problem is this translation 'to dwell in' or 'to possess' ignore the parallelism between Isaiah 62:4 and 62:5. The idea of these

1.Speak, now, in the hearing of all the leaders of Shechem, "Which is better for you, that 70 men, all the sons of Jerubbaal, rule over you, or that one man rule over you?' Also, remember that I am your bone and your flesh.

2.It will no longer be said to you, 'Forsaken', Nor to your land will it any longer be said, 'Desolate'; But you will be called, 'My delight is in her', And your land, 'Married'; For the Lord delights in you, and to him your land will be married.
TABLE 3: Translation of 'בעלוך' in Isaiah 62:5.

\begin{tabular}{|c|c|c|c|}
\hline Source & Text & Translation & Vorlage \\
\hline Septuagint & 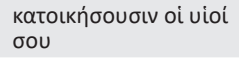 & Your sons will dwell & יבעלוך בניך \\
\hline Targum & 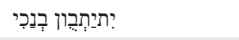 & Your sons co-inhabit & יבעלוך בניך \\
\hline Vulgate & habitabunt in te filii & Your sons will inhabit & יבעלוך בניך \\
\hline Aleppo Codex & 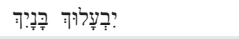 & Your sons will marry (or dwell) & יבעלוך בניך \\
\hline $1 Q \mid s a^{a}$ & יבעלוך בניך & Your sons will marry (or dwell) & יבעלוך בניך \\
\hline $1 Q \mid s a^{b}$ & יבעלוך בניך & Your sons will marry (or dwell) & יבעלוך בניך \\
\hline
\end{tabular}

passages is to convey that Zion is not alone anymore: 'עזכוּרָה' and 'שָמָמָה'. Therefore, the translation of 'marry' is more reasonable for both verse 4 and 5 .

This research, therefore, attempts to propose another reading for this incestuous problem in Isaiah 62:5.

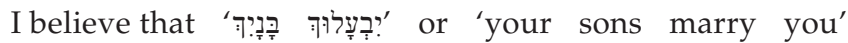
should be read metaphorically. Why? Firstly, Isaiah 62:5 employs imagery to depict the joyful and populous

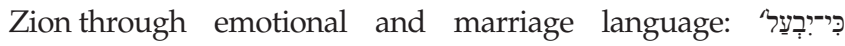

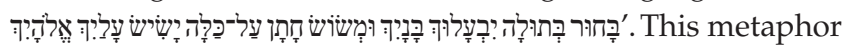
communicates that Zion will be filled with her inhabitants (Is 14:1; 49:20; 54:3; 60:4, 9, 21-22). The other scholars, such as Waard, Delitzsch, Beuken, support this interpretation (Beuken 1986-1989:229-230; Delitzsch 1889:592; Waard 1997:208). Therefore, the readers should understand 'your sons marry you' metaphorically. Secondly, the parallelism in Isaiah 62:5 itself. The exultation of the bridegroom over a bride is compared with God's rejoice over Zion and the marriage of a young man with a young woman, therefore, should be compared with the marriage of Zion with your sons.

\section{Conclusion}

The debatable identity in Isaiah 62:5 has been examined in this article. Textual criticism, external evidence, supports the translation of 'your sons' because most of ancient sources contain that reading. The internal evidence also favours this reading. The examination from parallelism in Isaiah 62:4-5, a lexical study of 'בניך', and a contextual endorse the reading of 'your sons'. Nevertheless, the reading of 'your sons' provides an incestuous sexual problem. This research, therefore,

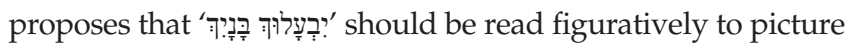
the joyful and populous Zion through emotional and marriage relationship. The implication of this research is to ensure God's protection and blessings upon his desolated and lost people.

\section{Acknowledgements Competing interests}

The author declares that he has no financial or personal relationships that may have inappropriately influenced him in writing this article.

\section{Author's contributions}

P.S.C. is the sole author of this article. 


\section{Ethical considerations}

This article followed all ethical standards for research without direct contact with human or animal subjects.

\section{Funding information}

This research received no specific grant from any funding agency in the public, commercial or not-for-profit sectors.

\section{Data availability}

Data sharing is not applicable to this article as no new data were created or analysed in this study.

\section{Disclaimer}

The views and opinions expressed in this article are those of the author and do not necessarily reflect the official policy or position of any affiliated agency of the author.

\section{References}

Baker, D.W. \& Walton, J.H., 2009, Zondervan illustrated Bible backgrounds commentary: Isaiah, Zondervan, Grand Rapids, MI.

Barthélemy, D., 1986, Critique Textuelle de L'Ancien Testament, Orbis Biblicus et Orientalis, 50/2, Editions Universitaires, Fribourg, Suisse.

Barthélemy, D., 2012, Studies in the text of the Old Testament: An introduction to the Hebrew Old Testament Text Project, Textual Criticism and the Translator, vol. 3, Eisenbrauns, Winona Lake, IN

Beuken, W.A.M., 1986-1989, Jesaja IIA, IIIA, IIIB, Callenbach, Nijkerk.

Brown, F., Driver, S.R., Briggs, C.A. \& Gesenius, W., 1952, A Hebrew and English Lexicon of the Old Testament: With an appendix containing the Biblical Aramaic, ed. G.R. Driver, transl. E. Robinson, Clarendon Press, Oxford.

Chia, P. \& Juanda, J., 2019a, 'A textual criticism and lexical analysis of Isaiah 62' Journal Didaskalia 2(2), 8-13. https://doi.org/10.33856/didaskalia.v2i2.138
Chia, P. \& Juanda, J., 2019b, 'A Hebrew Exegesis of Isaiah 62:1-5 The Restoration of Zion', Journal Kerugma 2(2), 57-66. https://doi.org/10.33856/kerugma. v2i 2.135

Chilton, B., 1987, The Isaiah Targum, The Aramaic Bible, vol. 11, M. Glazier Wilmington, DE.

Delitzsch, F., 1889, Commentar über das Buch Jesaia, Dörffling \& Franke, Leipzig.

Duhm, B., 1902, Das Buch Jesaia übersetzt und erklärt, Vandenhoeck \& Ruprecht, Göttingen.

Elliger, L. \& Rudolph, W. (eds.), 1967/1977/1997, Biblia Hebraica Stuttgartensia, Deutsche Bibelgesellschaft, Stuttgart.

Elowsky, J.C. (ed.), 2013, Commentary on Isaiah, Eusebius of Caesarea, Ancient Christian Texts, transl. J.J. Armstrong, InterVarsity Press, Downers Grove, IL.

Fischer, B. \& Weber, R., 1994, Biblia Sacra: iuxta vulgatam versionem (Ed. quartam emendatam), Deutsche Bibelgesellschaft, Stuttgart.

Kennicott, B., 1776-1780, Vetus Testamentum hebraicum cum variis Lectionibus, 2 vols., Oxford.

Lamy, T.J. (ed.), 1882-1902, 4 vols., Sancti Ephraem Syri hymni et sermones, H. Dessain, Mechliniae.

Lowth, R., 1778, Isaiah: A New Translation with ... Notes, Printed by J. Nichols for J. Dodsley, T. Cadell, London.

Marti, K., 1900, Das Buch Jesaja, Mohr, Tübingen.

McKenzie, J.L., 1968, Second Isaiah, Doubleday, Garden City, NY.

Oswalt, J., 1998, The book of Isaiah. Chapter 40-66, Wm. B. Eerdmans Publishing Co. Grand Rapids, MI.

Parry, D.W. \& Qimron, E., 1999, The great Isaiah Scroll (1Qisa $\left.a^{a}\right)$ : A new edition, Brill, Leiden.

Paul, S.M., 2012, Isaiah 40-66: Translation and commentary, the Eerdmans critical commentary, Eerdmans, Grand Rapids, MI.

Romeny, R.B.T.H. \& Van Peursen, W.T. (eds.), 1993, The Old Testament in Syriac: According to the Peshițta version, Part III. Fasc. 1. Isaiah, E.J. Brill, Leiden.

Ulrich, E., Flint, P.W. \& Abegg, M.G., 1990, Qumran Cave 1, Discoveries in the Judaean desert, 32, Clarendon Press, Oxford.

Waard, J., 1997, A handbook on Isaiah, Eisenbrauns, Winona Lake, IN.

Weber, R., et al. (eds.), 1983, Biblia Sacra iuxta Vulgatem Versionem, 3rd edn. Deutsche Biblegesellschaft, Stuggart, 1969.

Whybray, R.N., 1990, Isaiah 40-66, Wm. B. Eerdmans, Grand Rapids, MI.

Ziegler, J. (ed.), 1939, Isaias, Septuaginta: vetus testamentum graecum / auctoritate societatis litterarum gottingensis editum, vol. xiv, Akademie der Wissenschaften, Vandenhoeck \& Ruprecht, Göttingen. 